\title{
Cooperative Counselling Model with Jigsaw Technique in Improving Writing Quality of Official Letters
}

\author{
A Abbas \\ Universitas Hasanuddin Makassar, Sulawesi Selatan \\ \{asriani.abbas66@gmail.com\}
}

\begin{abstract}
The cooperative counseling model with the jigsaw technique for government staffs in Mandai Subdistrict, Maros Regency aims to improve the ability and skills to apply the standard language rules in writing official letters to the fullest. The method used is a jigsaw technique in the form of simulations, lecture demonstrations, and performances. The results of this counseling are expected to be the basis of planning in the form of constructive thoughts as an alternative solution for solving problems experienced by government staffs in Mandai District, Maros Regency, especially in official letter writing. The result of this research that the achievement of the success of writing the control group is twice that of the control group. The success of the jigsaw technique achievement is implemented in the experimental group that composes the letter based on the results of group discussions without being guided by the instructor/lecturer. Thus, counseling on cooperative models through jigsaw techniques in improving the quality of official letter writing is more successful than other techniques.
\end{abstract}

Keywords: cooperative counseling, jigsaw techniques, improving the quality, official letters.

\section{INTRODUCTION}

One of the mandates contained in the 1945 Constitution Chapter XV, Article 36 states that documents, decisions, correspondence issued by the government and state bodies must be written in Indonesian. Related to the mandate, in the implementation of government administration in the form of reciprocal communication between the government and the government, the government and the public must use standard Indonesian. The standard Indonesian language is a formal Indonesian language and has been agreed upon as a prestigious and highly dignified language. Along with the era of globalization which is getting more and more powerful, Indonesian language has begun to experience deterioration. It was found that writing official letters in several relevant agencies tended to ignore the standardized language rules, such as spelling writing, word formation, word selection, sentence formation, and the preparation of paragraphs [1]. There are also sentences compiled by following the structure of other languages, especially English and local languages. The consequence occurs that sometimes the letter sent does not get a quick response from the recipient of the letter because it is difficult to understand the contents of the letter received [2].

Another phenomenon faced is that so far observers, enthusiasts, extension workers, and language researchers still apply conventional methods, both in the form of direct and indirect 
counseling. Direct counseling is carried out in a face-to-face manner between participants and instructors by applying the expository method, which is a one-way lecture. The method emphasizes the mastery of as much material as possible so that counseling takes place uninteresting. Meanwhile, indirect counseling has also been carried out through electronic media, in the form of counseling on TVRI and RRI. Counseling on TVRI was carried out through the BINAR (True Indonesian Language) program, while counseling on RRI was carried out through the ACBI (Aku Cinta Bahasa Indonesia or I Love Indonesian), Mercu Bahasa, and Poets programs. However, these forms of counseling have not provided significant results in the application of standard Indonesian in their respective work environments because the time available is very limited. The limited time available is not possible to provide opportunities for extension participants to practice the insights that have been obtained. Conventional education activities are more marked by the culture of memorization than thinking. As a result, participants considered the counseling material to be memorized only. Such counseling models tend to be unattractive and do not provide maximum results.

Based on the problems that have been raised, I as the lecturer of Indonesian Department, Hasanuddin University as an educational institution that carries out one of the three tridharma (three main duties) of higher education, namely community service, feels the need to be involved in helping solve the problems faced by the relevant agencies. Therefore, the writer, a model of education was proposed which was seen to improve the quality of the application of the standard Indonesian language to government officials in writing official letters, especially in Mandai District, Maros Regency. The model is a form of cooperative counseling with a jigsaw technique.

\section{RESEARCH METHOD}

Etymologically, jigsaw comes from English, the "jigsaw" and people also call it the puzzle term, a puzzle that compiles pieces of cooperative learning. Gulo in Sudibyo expressed that cooperative learning is a learning strategy, that students are studying in small groups with heterogeneous cognitive abilities [3]. The philosophy that underlies cooperative learning (mutual learning) in education is "homo socius homo" which emphasizes that human beings are social creatures. Cooperative learning is a teaching-learning strategy that emphasizes shared attitudes or behaviors in working or helping one another in a well-organized structure of the group, consisting of two or more people.

Furthermore, cooperative learning with the jigsaw technique is a cooperative learning technique consisting of several members in one group who are responsible for mastering the learning material section and are able to teach the material to other members in the group [2]. The learning model was adapted into the counseling model. Asriani [3] expressed a reason that learning is synonymous with counseling because it is related to transferring knowledge to an interested audience. The counseling model in question emphasizes the development process of critical thinking and is able to search for alternative solutions to apply the standard Indonesian language rules in writing official letters in the scope of government.

The implementation of this activity was in the form of official letter writing training for government officials in Mandai Subdistrict, Maros Regency by applying a cooperative extension model with a jigsaw technique. After being given training, they were guided to apply the results of the training in order to improve their ability to write effective official letters. The training stages consists of the preparation and implementation stages of the training. 


\subsection{Preparatory stage}

Coordination with the Head of Mandai District, Maros Regency. Define the number of trainees, registering all employees directly related to correspondence matters. Participants are collected in a place/room that is adequate for the implementation of training.

\subsection{The training phase of the Training Method}

Presenting training material which includes: (1) explanation of the main concepts in implementing cooperative model counselling. Furthermore, also elaborated elements of cooperative counselling to achieve similar roles and responsibilities and shared desires to obtain satisfactory results; (2) grouping participants into small groups. Each group consists of 4 people with different abilities in order to be able to make the transition efficiently and work together with positive interdependencies and are responsible for completing the part of the counseling material that must be known and conveying the material to other group members.

Assign participants to write a letter whose theme has been determined which is guided by the counseling team. This group is called the home group. The number of members in the original group adapts to the number of parts of the letter material, namely spelling writing, word formation, word selection, sentence formation, and the preparation of paragraphs. which participants will write according to the purpose of counseling to be achieved.

Each participant is given the task of learning one part of the counseling material. All participants with the same counseling material learn together in groups called expert groups (counterpart group/CG). In the expert group, participants discuss the same part of the learning material, and plan how to convey to their friends if they return to their original group or the jigsaw group.

Each member of the expert group will return to the original group providing information that has been obtained or learned in a group of experts. After the participants have discussed in the expert group and the original group, then each group's presentation is carried out or one group is drawn to present the results of the group discussions that have been conducted so that the instructor can equate perceptions to the extension material that has been discussed.

Each member of the expert group will return to the original group providing information that has been obtained or learned in a group of experts. After the participants have discussed in the expert group and the original group, then each group's presentation is carried out or one group is drawn to present the results of the group discussions that have been conducted so that the instructor can equate perceptions to the extension material that has been discussed.

Carry out technical training skills in official letter writing by the way each instructor explains the application of standard Indonesian writing rules in writing official documents which include spelling writing, word formation, word selection, sentence formation, and paragraph preparation.

Presentation results from each group are determined in a decision based on the results of a collective agreement related to the rules of writing the standard Indonesian language in writing official letters that have been explained by the instructors. The activity is guided by the instructor so that the discussion takes place systematically, safely, and creates an atmosphere of counseling that is more comfortable to provide information to each other and does not come out of the subject matter that has been agreed upon. 


\subsection{Program Implementation and Evaluation}

The thinking framework for problem solving can be presented in the form of the following matrix:

\begin{tabular}{ll}
\hline \multicolumn{1}{c}{ Problem } & \multicolumn{1}{c}{ Problem Solving Efforts } \\
\hline $\begin{array}{l}\text { How to motivate government officials to } \\
\text { write effective official letters }\end{array}$ & $\begin{array}{l}\text { Introduced a model of cooperative } \\
\text { counseling with jigsaw techniques that is } \\
\text { innovative, creative, and adaptive. }\end{array}$ \\
$\begin{array}{l}\text { What is the understanding of government } \\
\text { Counseling/upgrading was carried out which } \\
\text { was filled with the implementation of a }\end{array}$ \\
$\begin{array}{l}\text { Indonesian language code? The nature of } \\
\text { writing official letters includes: }\end{array}$ & $\begin{array}{l}\text { cooperative model with the jigsaw technique, } \\
\text { including methods for providing case }\end{array}$ \\
(1) spelling writing; & $\begin{array}{l}\text { examples and question and answer/discussion } \\
\text { to produce collective agreements. }\end{array}$ \\
(3) word formation; & \\
(4) sentence formation; and & \\
(5) preparation of paragraph. & \\
\hline
\end{tabular}

Evaluation was carried out to measure the level of achievement of the jigsaw method of counseling in the process of developing critical thinking and the search for alternative solutions to apply the standard Indonesian language rules in official letter writing in the scope of government [7].

\section{RESULT AND DISCUSSION}

\subsection{Preparation for Implementation of Activities}

The community service activities carried out technically involved collaboration between the Research and Community Service Institution (LP2M) of Hasanuddin University and the Office of the Mandai District Head of Maros Regency as a recommendation/letter of willingness to cooperate. The activity began with a visit of the chair of the activity, Dr. Asriani Abbas, M. Hum., to the Mandai Subdistrict Head, Andi Mappelawa, S. Sos., M.Si., in BontoBontoa, Maros Regency on Monday, July 16, 2018. This visit was a coordination of the activities that resulted in an agreement, namely government official letter writing training activities in Mandai Subdistrict, Maros Regency with the application of a cooperative counseling model with the jigsaw technique carried out on Friday, August 3, 2018; the timing of the training activities takes place from 9 am to $4 \mathrm{pm}$; the place for conducting training activities in the second floor hall of the Mandai sub-district office, Maros Regency; and the training participants were 25 administrative staff/correspondence for the government office in the sub-district of Maros and allowed to add up to 30 people.

\subsection{Implementation of Activities}

On Friday, August 3, 2018, the community service team of Hasanuddin University had prepared the material, namely Dr. Ikhwan M. Said, M.Hum., The training material is the Use of Spelling in Writing Office Letters; Dr. Asriani Abbas, M. Hum., With the activities of 
Effective Application of Sentences in Writing Office Letters; and Dr. Munira Hasjim, S.S., the material is the Preparation of Paragraphs in Writing Office Letters.

Participants who were initially estimated to be only 25 people, it turned out that there were 30 participating administrative staff/correspondents in the government office in the Maros Subdistrict. According to the Mandai Subdistrict Head, Andi Mappelawa, S.Sos., M.Si., this increase was due to the many staff who were interested in participating in the training. The training activity was opened by the Secretary of the Mandai Subdistrict together with the Chair of the Indonesian Literature Department.

Furthermore, the community service team presented the material in a detailed manner. After the Friday Prayer, the participants conducted a jigsaw technique of writing a letter writing in two groups, namely experiment and control. The experimental group consisted of 15 people, while the control group consisted of 15 people. Participants were divided into 2 groups, namely the experimental group and the control group.

Experimental group consists of 15 people divided into 4 groups and each group composes a letter based on the results of group discussions without being guided by instructors /lecturers. Next, each group was represented by one of its members to present the results of their group work, then responded by another group. The instructor/lecturer provides improvements to the writing of letters in accordance with the rules of good and correct Indonesian. Control group is 15 participants who compose the letter by getting guidance from the instructor/lecturer. One person presented his work, then corrected by the instructor/lecturer.

\subsection{Achievement Result}

Evaluation is a control of the achievement of the success of the training that has been implemented. This evaluation was still compiled and analyzed to be described based on the achievements in the control group and the experimental group. The assessment criteria and measurement scale are adapted from Lukman in Brown [8] which consists of five levels, which are very good with a weight of 90-100; good with a weight of 80-89; enough with a weight of 70-79; less weighing 50-69; and very less with a weight of less than 50 . The criteria mentioned above can be seen in the frequency distribution of the ability to write official letters in the experimental group and the control group.

Table 1. Frequency Distribution of the Ability to Write Experimental Group Service Letters

\begin{tabular}{cccc}
\hline No. & Criterium & Amount & Percentage \\
\hline 1. & $90-100$ & 6 & 40.5 \\
2. & $80-89$ & 7 & 46.7 \\
3. & $70-79$ & 2 & 12.7 \\
4. & $50-59$ & 0 & 0 \\
5. & $<50$ & 0 & 0 \\
\hline & Total & 15 & 100 \\
\hline
\end{tabular}

In table 1 . which is the evaluation value of the work results of the experimental group, there are 6 people who reach a very good category with values between $90-100$ (40.5\%). Meanwhile, participants with good categories achieved grades between 80-89 as many as 7 people (46.7\%). Furthermore, participants who obtained 70-79 scores with enough categories were 2 people $(12.7 \%)$. There were no participants who obtained the results of the category of less and very less. 
Table 2. Frequency Distribution of the Ability to Write Control Group Service Letters

\begin{tabular}{cccc}
\hline No. & Criterium & Amount & Percentage \\
\hline 1. & $90-100$ & 3 & 20.0 \\
2. & $80-89$ & 3 & 20.0 \\
3. & $70-79$ & 7 & 46.7 \\
4. & $50-59$ & 2 & 12.7 \\
5. & $<50$ & 0 & 0 \\
\hline & Total & 15 & 100 \\
\hline
\end{tabular}

Data in table 2 shows that the percentage of procurement value of control group work is 3 or $20.0 \%$ which is very good value. Meanwhile, the participants reached a score of $80-89$ with a good category of 3 or $20.0 \%$. Then the score $70-79$ with category enough as 7 people or $46.70 \%$. There are 2 people in the category of less, ie $12.7 \%$. No participant has a very poor category.

Comparison of data in table 1 and 2 become a benchmark for the success of counseling cooperative models through jigsaw techniques in improving the quality of official letter writing in Mandai District, Maros Regency. The following is a comparison of the work data between the experimental group and the control group.

Table 3. Comparison of the Achievement of the Frequency of the Writing Ability of Official Letters in the Experimental Group and the Control Group

\begin{tabular}{|c|c|c|c|c|c|c|c|c|}
\hline \multicolumn{2}{|c|}{$\begin{array}{l}\text { KELOMPOK } \\
\text { EKSPERIMEN }\end{array}$} & \multirow[t]{3}{*}{ KRITERIA } & \multicolumn{2}{|c|}{$\begin{array}{c}\text { KELOMPOK } \\
\text { KONTROL }\end{array}$} & \multicolumn{4}{|c|}{ ATTENDANCE OF CAPITAL } \\
\hline \multirow{2}{*}{ Jumlah } & \multirow{2}{*}{ Persentase } & & \multirow{2}{*}{ Jumlah } & \multirow{2}{*}{ Persentase } & \multicolumn{2}{|c|}{ Eksperimen } & \multirow{2}{*}{\multicolumn{2}{|c|}{$\begin{array}{c}\text { Kontrol } \\
\text { Jumlah Persentase }\end{array}$}} \\
\hline & & & & & Jumlah & Persentase & & \\
\hline 6 & 40.5 & $90-100$ & 3 & 20.0 & +3 & +20.5 & -3 & -20.5 \\
\hline 7 & 46.7 & $80-89$ & 3 & 20.0 & +4 & +26.7 & -4 & -26.7 \\
\hline 2 & 12.7 & $70-79$ & 7 & 46.7 & -5 & -34.0 & +5 & +34.5 \\
\hline 0 & 0 & $50-59$ & 2 & 12.7 & -2 & -12.7 & +2 & +12.7 \\
\hline 0 & 0 & $<50$ & 0 & 0 & 0 & 0 & 0 & 0 \\
\hline 15 & 100 & & 15 & 100 & & & & \\
\hline
\end{tabular}

Based on the data in table 3 above it can be explained that the work results of the experimental group experienced significant progress compared to the control group. Comparison of achievements as follows: (1) no experimental group had less and very less categories, while the control group had 2 people; (2) the number of participants in the experimental group in the excellent and good category was 13 people, while the control group was only 6 people; (3) the percentage of achievement of the experimental group for the excellent and good category is 87.2 , while the control group is only 40 .

This comparison shows that the success of counseling cooperative models through jigsaw techniques in improving the quality of writing official documents in Mandai Subdistrict, Maros Regency is twice than other techniques. The success of the jigsaw technique achievement is implemented in the experimental group that composes the letter based on the results of group discussions without being guided by the instructor/lecturer. 


\subsection{Outsourced}

The results achieved from these community service activities can be detailed as follows: (1) the cooperative education model with the jigsaw technique was able to improve the ability to write official letters of government officials in Mandai Subdistrict, Maros Regency; (2) the model of cooperative counseling with jigsaw techniques that is innovative, creative, and adaptive provides in-depth knowledge and provides capabilities and skills to government officials to make letters effectively; (3) The model of cooperative counseling through jigsaw techniques has become a benchmark for the development and extension of Indonesian language as an alternative solution to solve all problems experienced by government officials related to the application of standard language rules in official letter writing [9].

The model of cooperative counseling with the jigsaw technique is able to improve the ability to write official government official letters in Mandai Subdistrict, Maros Regency, published at the International Conferences on Advances In Humanities, Education and Language (ICEL) on March 23, 2019 at University of Brawijaya Malang, Indonesia.

\section{CONCLUSIONS}

The success of counseling cooperative models through jigsaw techniques in improving the quality of writing official letters in Mandai Subdistrict, Maros Regency can be measured by comparing the performance results of the experimental group and the control group. The achievement of the success of writing the control group is twice that of the control group. The success of the jigsaw technique achievement is implemented in the experimental group that composes the letter based on the results of group discussions without being guided by the instructor/lecturer. Thus, counseling on cooperative models through jigsaw techniques in improving the quality of official letter writing is more successful than other techniques.

Other results achieved from the cooperative counseling model with the jigsaw technique, namely being able to improve the ability to write official letters of government officials in Mandai Subdistrict, Maros Regency; provide in-depth knowledge and provide capabilities and skills to government officials to make letters effectively; and become a benchmark for the development of Indonesian language guidance and counseling as an alternative solution to solve all problems experienced by government officials related to the application of standard language rules in writing official documents.

Based on the results achieved in the successful extension of cooperative models through jigsaw techniques in improving the quality of official letter writing in Mandai Subdistrict, Maros Regency, it is recommended that this model be applied to counseling in the field of cognition, such as literature studies, linguistics, and cultural socialization.

\section{REFERENCES}

[1] B. Sudibyo Bambang, Materi Road Show Dewan Pendidikan Bersama Tim Wajar Dikdas Kabupaten Kuningan. Kuningan: Dewan Pendidikan Kabupaten Kuningan, 2008.

[2] J.A. Banks, Teaching Strategies For The Social Studies (Inquiry, Valuing, And Decision Making). New York and London: Longman, 1990.

[3] A. Abbas, Pengembangan Model Penyuluhan Kooperatif dengan Teknik Diskoveri Inkuiri dalam Penulisan Surat-surat Dinas pada Lingkup Pemerintah Kabupaten Bantaeng. Hasil Penelitian Benua Maritim Indonesia Spesifik (BMIS). Makassar: LP2M Universitas Hasanuddin, 2016. 
[4] S. Rokhmatika, Pengaruh Model Inkuiri terbimbing Dipadu Koperatif Jigsaw terhadap Keterampilan Proses Sains Ditinjau dari kemampuan Aademik. 2012.

[5] Lukman et al, Model Pembelajaran Kooperatif dengan Teknik Peer Feedback dalam Meningkatkan Keterampilan Menulis Karya Ilmiah Mahasiswa: Kajian Eksperimental. Hasil Penelitian BOPTN. Makassar: FIB Universitas Hasanuddin, 2014.

[6] Bell, L. C., \& Perfetti, C. A. (1994). Reading Skill: Some Adult Comparisons. Journal of Educational Psychology, 86(2), 244-255.

[7] Nation, P. (2006). How Large a Vocabulary Is Needed For Reading and Listening? The Canadian Modern Language Review, 63(1), 59-82.

[8] Schmitt, N., Jiang, X., \& Grabe, W. (2011). The Percentage of Words Known in a Text and Reading Comprehension. The Modern Language Journal, 95(i), 26-43. doi: 10.1111/j.1540-4781.2011.01146.x

[9] Sanchez, A. P., \& Schmitt, N. (2012). Scoring Yes-No vocabulary tests: Reaction time vs. nonword approaches. Language Testing, 0, 1-21. doi: 10.1177/0265532212438053 